\title{
Present status of soil nutrient and tree stands density of Sundarbans mangrove forest of Bangladesh
}

\author{
Mohammad Kamrul Hasan`, G. M. Mujibar Rahman and Rojina Akter \\ Department of Agroforestry, Bangladesh Agricultural University, Mymensingh-2202, Bangladesh. \\ *Corresponding author. Email: mkhasanaf@bau.edu.bd
}

Copyright @ 2018 Hasan et al. This article remains permanently open access under the terms of the Creative Commons Attribution License 4.0, which permits unrestricted use, distribution, and reproduction in any medium, provided the original work is properly cited.

Received 31st October, 2018; Accepted 17th December, 2018

\begin{abstract}
The study was conducted in Khulna and Satkhira ranges of western Forest Division to determine the present nutrient status in soils and tree stand density of Sundarbans mangrove forest of Bangladesh during February to May 2016. Sampling was carried out at 46 sites from two locations viz. 23 sampling sites were from Khulna forest range and 23 sites from Satkhira range. The soil samples were collected at two depths viz. surface $(0$ to $15 \mathrm{~cm})$ and sub-surface $(15$ to 30 $\mathrm{cm}$ ) layers of soil. Tree-related data like name of the species, a number of trees/plots were recorded for all the natural trees having a diameter at breast height $(\mathrm{dbh}) \geq 10 \mathrm{~cm}$ to calculate the stand density in the study area marked $10 \mathrm{~m} \times 10 \mathrm{~m}$ quadrate sample plots randomly. The collected soil samples were analyzed in a laboratory to determine the nutrient status. The result revealed that the soils of Sundarbans mangrove forest in Bangladesh were neutral to saline and the $\mathrm{pH}$ values (7.6) of surface soils were higher compared to sub-surface soils. The results also indicate that organic matter, total $\mathrm{N}$, available $\mathrm{P}, \mathrm{Ca}, \mathrm{Mg}, \mathrm{S}, \mathrm{Fe}, \mathrm{B}$ and $\mathrm{Zn}$ were observed comparatively higher $(1.65 \%, 0.09 \%, 19.26 \mathrm{ppm}, 9.11 \mathrm{meq} / \mathrm{ml}$, $2.92 \mathrm{meq} / \mathrm{ml}, 169.59 \mathrm{ppm}, 22.72 \mu \mathrm{g} / \mathrm{ml}, 0.66 \mu \mathrm{g} / \mathrm{ml}$ and $4.22 \mu \mathrm{g} / \mathrm{ml}$, respectively) in surface soils except for exchangeable $\mathrm{K}$ which was higher $(1.55 \mathrm{meq} / 100 \mathrm{~g})$ in sub-surface soils. However, the tree stands density in Sundarbans mangrove forest was recorded as 525 trees/ha and 569 trees/ha in Khulna and Satkhira forest ranges, respectively. Therefore, the information of this study would be helped to the researcher and policymaker for better understanding and management of Sundarbans.
\end{abstract}

Keywords: Mangrove forest, surface and sub-surface soils, soil nutrient status, tree stand density.

\section{INTRODUCTION}

Bangladesh is a South Asian developing country with an area of $147,57,000$ ha. However, the agricultural land covers about $65 \%$, forest lands account for almost $17 \%$ and $18 \%$ for others from the total area of Bangladesh. But practically, Bangladesh has only $9.5 \%$ of forest coverage though it requires at least $25 \%$ for ecological balance (BFD, 2017). The Sundarbans is the largest tidal halophytic mangrove forest in the world which covers $23.8 \%$ of the total forest area of Bangladesh (BFD, 2017). The Sundarbans is very rich in biodiversity supports versatile interactions and correlations and relationships among its vertebrates and invertebrates, flora, fauna, aquatic organisms, marine lives, wildlife, fishes, birds, natural habitats (Awal, 2007). Sundari (Heritiera fomes) is the main tree species which covers about $60 \%$ of the total area (BFD, 2017). The Sundarbans is one of the valuable natural assets of Bangladesh which provides economic, social and ecological benefits. But presently, this forest is losing its soil fertility and biodiversity day by day for both natural and man-made reasons like illegal cutting, shrimp culture and climate change as well as environmental pollution, all of which have a great impact on the forest ecosystem. For the sustainability of existing forest coverage, increasing soil nutrient content and maintenance of the site, it is utmost necessary to maintain the stand density of the forest. Within a forest stand, nutrients exist in many forms and distinct pools and are cycled between soils and plants. The most important nutrients in forests are the macronutrients which are needed directly for plant growth. Micronutrients are also required by plants, but are usually abundant in soils and rarely limit plant growth (Binkley, 1986). Plants uptake 
nutrients from the soil solution and incorporate them into biomass, which is then returned to the soil through litter fall, root turnover, and tree mortality. This biomass or organic matter is then decomposed by soil organisms such as bacteria and fungi that excrete enzymes to break down organic molecules into smaller units, liberating nutrients and making them available to plants again (Chapin et al., 2002). So, forest soils influence the composition of the forest stand and ground cover, rate of tree growth, vigor of natural reproduction and other silviculturally important factors. Several studies on the physical and chemical status of mangrove and coastal soils have been investigated throughout the world and Indian sub-continent by various researchers (Ramamurthy et al., 2012; Arianto et al., 2015; Barik et al., 2018). But in Bangladesh, only a few worked were conducted on Sundarbans forest soils which are not sufficient (Muhibbullah et al., 2005; Rashid et al., 2007; Hossain et al., 2012; Hossain and Bhuiyan, 2015). Therefore, the study was undertaken to analyze the present status of soil nutrient and account of tree stand density of Sundarbans mangrove forest of Bangladesh. For answering the preceding objective, the study set forth a hypothesis tested with data gathered on the present status of soil nutrient and tree stand density of Sundarbans mangrove forest was unknown.

\section{MATERIALS AND METHODS}

\section{Study area}

The study was conducted from February to May 2016 at Sundarbans mangrove forest which is located at the southwest part of Bangladesh (Figure1). The Sundarbans mangrove forest is situated between $21^{\circ} 30^{\prime}$ and $22^{\circ} 30^{\prime}$ North latitude and $89^{\circ}$ and $90^{\circ}$ East longitudes. This forest consists of four different ranges viz. Sarankhola, Chandpai, Khulna and Satkhira. Among the four ranges, Khulna and Satkhira were selected for the study area (Figure 1). The climatic condition of the study areas: the average annual maximum temperature is around $35^{\circ} \mathrm{C}$. Average annual rainfall is $1920 \mathrm{~mm}$. The average relative humidity is about $82 \%$ and more or less uniform throughout the year (Sadiqul Amin, 2016). The soil of this forest is in general medium textured, sandy loam, silt loam or clay loam. Silt loam is dominant textural class. Organic matter content varies between $4 \%$ and $10 \%$ in dry soil (Banglapedia, 2012). The soil is saline in nature and it remains wet due to inundation of low-lying areas in two times of every day (Banglapedia, 2012). In this forest, Sundari (Heritiera fomes) is the dominant tree species which is distributed over $60 \%$ of the reserve. Besides, other species like Gewa (Excoecaria agallocha), Keora (Sonneratia apetala), Baen (Avicennia officinalis), Pasur (Xylocarpus mekongensis), Hental (Phoenix pelludosa), Golpata (Nypa fruticans), Kankra (Bruguiera gymnorhiza), Goran (Ceriops decandra), Jhana (Rhizophora mucronata) etc. are also found (BFD, 2017).

\section{Sampling design and plot measurement}

The total 46 sampling sites were selected from the study area where the 23 sites were in Khulna range like $S_{1}$ to $S_{23}$ and 23 sites were in Satkhira range like $S_{24}$ to $S_{46}$ (Figure 1 and Table 1). The $10 \mathrm{~m} \times 10 \mathrm{~m}$ quadrate plot was measured randomly from each sampling site for necessary sample collection and data recording.

\section{Soil sample collection and preparation}

Total of 92 soil samples was collected at two depths of soils of 0 to $15 \mathrm{~cm}$ (surface) and 15 to $30 \mathrm{~cm}$ (subsurface) from the study sites. From each quadrate plot, five soil cores were taken and mixed to make a composite sample. Then the soil samples were air dried, processed and sieved through 20 mesh sieve and packed with a specific tag for laboratory analysis.

\section{Collection of tree-related data}

Tree-related data were recorded from the same plot (10 $m \times 10 \mathrm{~m}$ ) in the time of soil sampling. Tree species were identified in the spot through visual observation. From each quadrate plot, a number of trees species/plot was recorded which having the diameter at breast height (dbh) $\geq 10 \mathrm{~cm}$ for calculating the trees stands density. Stand density was determined for each species using the estimated number of trees and basal areas of the species per hectare. The estimated number of trees of each species per hectare was obtained by extrapolating the total number of trees enumerated in the respective plots using the formula (Etigale et al., 2013):

$N=h / a \times c$

Where: $\mathrm{h}=$ one hectare, $\mathrm{a}=$ area of the plot in a hectare, $\mathrm{C}=$ number of trees counted in the plot and $\mathrm{N}=$ estimated number of trees per hectare.

The basal area of each tree was calculated with the basal area function as stated by Avery and Burkhart (2002). The formula is:

$\mathrm{BA}=\frac{\pi D^{2}}{4(100)}$

Where: $\mathrm{BA}=$ Basal Area $\left(\mathrm{m}^{2}\right), \pi=$ Constant (3.142) and $D$ $=$ Diameter at breast height $(\mathrm{cm})$.

Total basal area of each species was obtained by calculating together the basal areas of the individuals of the species. Basal area of each species per hectare was anticipated by extrapolating the total basal area of the species using the formula: 


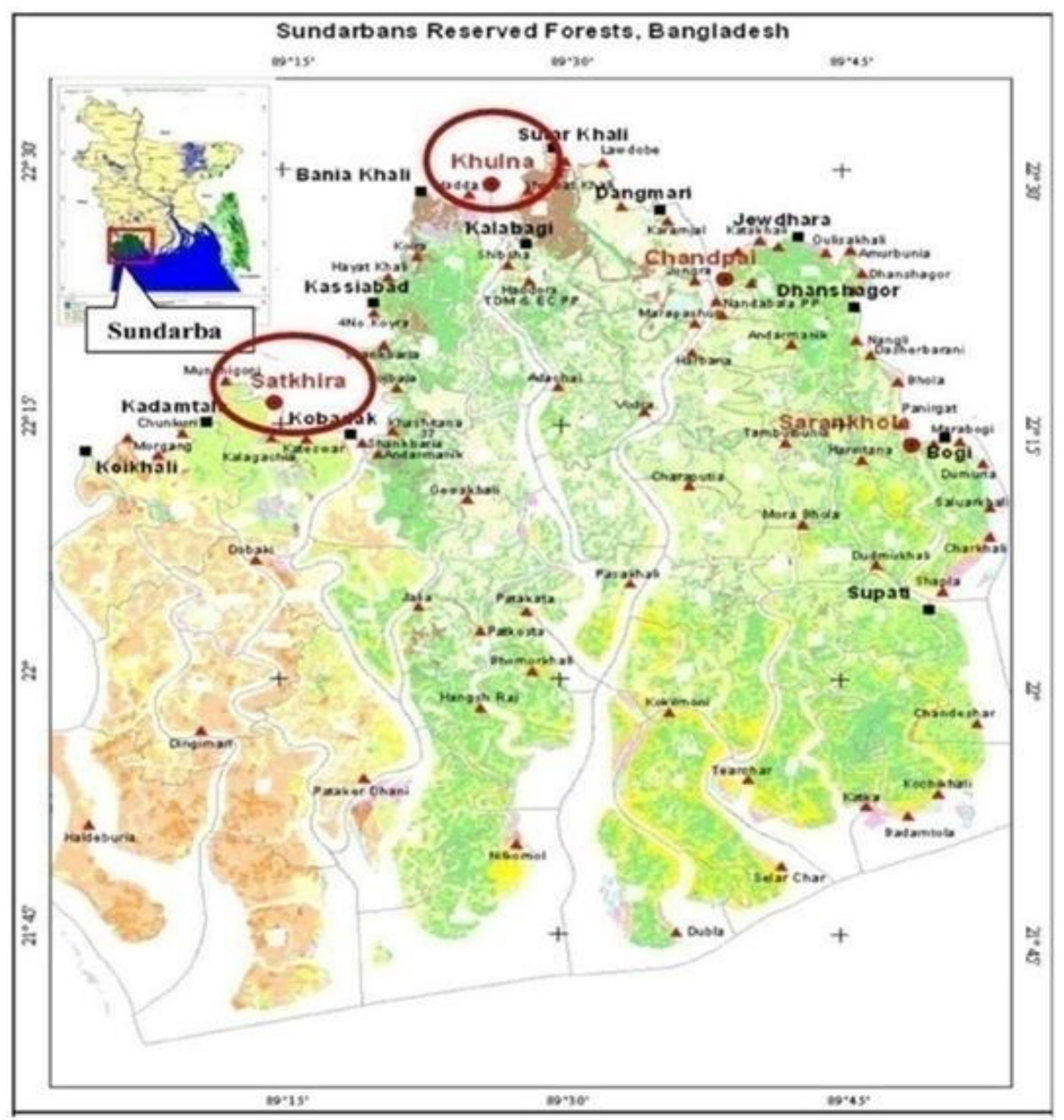

Figure 1. Showing the specific study sites at the location map of the Sundarbans mangrove forest in Bangladesh (Source: Forest Department, Bangladesh).

$B A=h / a \times d$

Where: $\mathrm{BA}=$ basal area per hectare, $\mathrm{h}=$ one hectare, $\mathrm{a}=$ area of the plot in a hectare and $d=$ basal area in each plot.

\section{Soil sample analysis}

The prepared soil samples were analyzed in Humboldt Soil Testing Laboratory, Soil Science Department, Bangladesh Agricultural University, Mymensingh and Soil Science Division, Bangladesh Agricultural Research Institute,
Joydebpur, Gazipur. Soil pH was measured by using Glass-electrode $\mathrm{pH}$ meter (WTW pH 522) at a soil-water ratio of 1:2. Organic carbon was determined by the wet oxidation method of Walkley and Black (1934). Total nitrogen was determined by the micro-Kjeldahl method (Jackson, 1958). Available $P$ was extracted by the Molybdenum blue method of Bray and Kurtz using a spectrophotometer (Jackson, 1958). Exchangeable K was determined by $1 \mathrm{~N} \mathrm{NH}{ }_{4} \mathrm{OAc}$ extract method using flame photometer (Page et al., 1989). Available $\mathrm{Ca}$ and $\mathrm{Mg}$ was extracted with $1 \mathrm{~N} \mathrm{NH}_{4} \mathrm{OAc}$ using an atomic absorption spectrophotometer method (Peterson, 2002). Sulfur (S) 
Table 1. Description of the study sites

\begin{tabular}{|c|c|c|c|}
\hline Forest Ranges & Sites No. & Name of the sites & Tree species \\
\hline \multirow{23}{*}{ Khulna } & $\mathrm{S}_{1}$ & Shibsa river site & Sundori, Bain \\
\hline & $\mathrm{S}_{2}$ & Shibsa khal & Keora, Bain \\
\hline & $\mathrm{S}_{3}$ & Hodda forest station & Sundori, Poshur, Kankra \\
\hline & $\mathrm{S}_{4}$ & The midpoint of Hodda and Kali khal & Gewa \\
\hline & $\mathrm{S}_{5}$ & Kali khal & Poshur, Kankra \\
\hline & $\mathrm{S}_{6}$ & Bharani khal & Sundori \\
\hline & $\mathrm{S}_{7}$ & Jhora khal & Gewa \\
\hline & $\mathrm{S}_{8}$ & Phultola khal east & Khulshi, Gewa \\
\hline & $\mathrm{S}_{9}$ & Phultola khal west & Kankra, Bain, Poshur \\
\hline & $\mathrm{S}_{10}$ & Joymuri khal & Bain, Kankra \\
\hline & $S_{11}$ & Boumara khal & Sundori, Bain, Kankra \\
\hline & $\mathrm{S}_{12}$ & Kaintabari khal & Khulshi, Sundori \\
\hline & $\mathrm{S}_{13}$ & Torudhunia khal & Kankra, Poshur \\
\hline & $\mathrm{S}_{14}$ & Baniakhali khal & Bain, Gewa, Kankra \\
\hline & $\mathrm{S}_{15}$ & Gabbunia & Khulshi, Jhana \\
\hline & $S_{16}$ & Boropata khali & Sundori, Kankra \\
\hline & $\mathrm{S}_{17}$ & Chotopata khali & Bain, Kankra \\
\hline & $\mathrm{S}_{18}$ & Ghoramir khal & Gewa \\
\hline & $\mathrm{S}_{19}$ & Horipur & Goran, Bain \\
\hline & $\mathrm{S}_{20}$ & Choto Hossain khali & Bain \\
\hline & $\mathrm{S}_{21}$ & Boro Hossain Khali & Keora, Bain \\
\hline & $\mathrm{S}_{22}$ & Tong Ghor khal & Sundori, Bain \\
\hline & $\mathrm{S}_{23}$ & Boj Boja Forest Station & Keora, Gewa, Jhana \\
\hline \multirow{23}{*}{ Sathkhira } & $\mathrm{S}_{24}$ & Munshigonj forest station & Keora, Jhana \\
\hline & $\mathrm{S}_{25}$ & Choto Kewakhali khal North & Bain, Goran, Poshur \\
\hline & $\mathrm{S}_{26}$ & Choto Kewakhali khal & Bain, Goran \\
\hline & $\mathrm{S}_{27}$ & Boro Kewakhali khal & Kankra, Bain, Goran \\
\hline & $\mathrm{S}_{28}$ & Kolagachi East & Dhundol \\
\hline & $\mathrm{S}_{29}$ & Kolagachi North-1 & Khulshi \\
\hline & $\mathrm{S}_{30}$ & Kolagachi North-2 & Keora \\
\hline & $\mathrm{S}_{31}$ & Kolagachi Forest Toholfai & Poshur \\
\hline & $\mathrm{S}_{32}$ & Kolagachi Forest Toholfai & Poshur, Keora \\
\hline & $\mathrm{S}_{33}$ & Kolagachi Forest Toholfai & Kankra \\
\hline & $\mathrm{S}_{34}$ & Kolagachi Forest Toholfai & Khulshi \\
\hline & $\mathrm{S}_{35}$ & Kolagachi South-1 & Jhana, Khulshi \\
\hline & $\mathrm{S}_{36}$ & Kolagachi South-2 & Khulshi \\
\hline & $\mathrm{S}_{37}$ & Kolagachi West-1 & Sundori \\
\hline & $\mathrm{S}_{38}$ & Kolagachi West-2 & Keora \\
\hline & $\mathrm{S}_{39}$ & Kolagachi North & Sundori \\
\hline & $\mathrm{S}_{40}$ & Dobaki & Bain, Jhana \\
\hline & $\mathrm{S}_{41}$ & Kadamtala & Bain, Goran, Poshur \\
\hline & $\mathrm{S}_{42}$ & Chunkuri-1 & Sundori, Bain \\
\hline & $\mathrm{S}_{43}$ & Chunkuri-2 & Keora, Jhana \\
\hline & $\mathrm{S}_{44}$ & Moragang-1 & Khulshi, Jhana \\
\hline & $\mathrm{S}_{45}$ & Moragang-2 & Bain, Goran, Poshur \\
\hline & $\mathrm{S}_{46}$ & Koikhali & Poshur, Khulshi \\
\hline
\end{tabular}

was determined by a turbidimetric method using a spectrophotometer (Page et al., 1989). Available Fe and
$\mathrm{Zn}$ were determined by a diethylenetriaminepentaacetic acid (DTPA) extraction method using an Atomic 
Absorption Spectrophotometer (AAS) (Peterson, 2002). Boron (B) was determined by spectrophotometer technique using a colorimetric reaction with Azomethine- $\mathrm{H}$ (Ogner, 1980).

\section{Statistical analysis}

The collected data were tabulated and analyzed through a standard computer package statistical procedure MSTATC, MS Excel and SPSS software (Gomez and Gomez, 1984). Mean values of soil parameters were computed and employed to compare the results with the relevant findings. A critical limit for interpreting levels of soil nutrient parameters was adopted from Fertilizer Recommendation Guide (2012).

\section{RESULTS AND DISCUSSION}

\section{Soil pH}

The $\mathrm{pH}$ values of the soil samples collected from Khulna and Satkhira ranges of Sundarbans mangrove forest of Bangladesh are presented in Table 2. The $\mathrm{pH}$ values in the surface and sub-surface soils across the different sites of Khulna range varied from 7.22 to 7.92 and 7.10 to 7.82 , respectively. Similarly, the $\mathrm{pH}$ values in the surface and sub-surface soils across the sites of Satkhira range varied from 7.30 to 7.96 and 7.18 to 7.86 , respectively (Table 2). The average of Khulna and Satkhira ranges soils $\mathrm{pH}$ values are presented in Table 6 . The average $\mathrm{pH}$ value (7.64) of the surface soils was found higher than the sub-surface soils (7.56) of Sundarbans mangrove forest (Table 6). The results indicated that the soils of the mangrove forest of Sundarbans were neutral to saline in nature and soil salinity might have developed due to the inundation of saline sea water into the forest. Joshi and Ghose (2014), Rao and Rao (2014), Maniruzzarnan et al. (2009) and Muhibbullah et al. (2005) found that the soils of Sundarbans was heavy and slightly saline to saline with high salinity variation where $\mathrm{pH}$ ranged from 7.1 to 8.79 which is very much closed to the result of present findings.

\section{Organic matter}

The results of organic matter revealed that the surface and sub-surface soils of Khulna forest range across the sites varied from 1.15 to $1.97 \%$ and 1.12 to $1.84 \%$, respectively while the organic matter content of Satkhira forest range across the sites varied from 1.58 to $2.04 \%$ and 1.18 to $1.84 \%$, respectively (Table 2 ). The result also revealed that the average content $(1.65 \%)$ of organic matter of surface soils was observed higher than the sub-surface soils (1.45) of Sundarbans mangrove forest (Table 6). From the result, it can be explained that organic matter content of soils of Sundarbans mangrove forest was low to medium and this might be due to the removal of leaf litter from the forest floor during inundation. Hossain and Bhuiyan (2015), Hossain et al. (2012) and Maniruzzarnan et al. (2009) found a similar result which is closed to the present study.

\section{Status of soil macronutrients}

\section{Primary nutrients $(N, P, K)$}

The results of the total $\mathrm{N}$ content of soils at two depths viz. 0 to $15 \mathrm{~cm}$ and 15 to $30 \mathrm{~cm}$ of Khulna range across the sites varied from 0.06 to $0.20 \%$ and 0.05 to $0.11 \%$, respectively (Table 3 ). Similarly, the values of total $\mathrm{N}$ of soils of Satkhira range across the sites varied from 0.07 to $0.22 \%$ at 0 to $15 \mathrm{~cm}$ depth and 0.05 to $0.10 \%$ at 15 to $30 \mathrm{~cm}$ depth (Table 3 ). From the results, it was observed that the values of available $P$ varied from 16.5 to $28.07 \mathrm{ppm}$ at 0 to $15 \mathrm{~cm}$ depth and 14.8 to $22.63 \mathrm{ppm}$ at 15 to $30 \mathrm{~cm}$ soil depth at Khulna range (Table 3 ). While in Satkhira range, the available $P$ content in soils varied from 13.61 to $24.50 \mathrm{ppm}$ at 0 to $15 \mathrm{~cm}$ depth and 15.65 to $21.94 \mathrm{ppm}$ at a 15 to $30 \mathrm{~cm}$ soil depth. Comparing to the Fertilizer Recommendation Guide (2012) of Bangladesh, the available P content of the present study was high to very high at both Khulna and Satkhira ranges of Sundarbans mangrove forest (Table $3)$. It was also observed from the results that the average values of total $N(0.09 \%)$ and available $P$ (19.26 ppm) were higher in surface soils compared to sub-surface soils of Sundarbans mangrove forest (Table 6). The values of exchangeable $\mathrm{K}$ of surface and sub-surface soils of Khulna range varied from 0.57 to $1.60 \mathrm{meq} / 100 \mathrm{~g}$ and 0.82 to $1.71 \mathrm{meq} / 100 \mathrm{~g}$, respectively. While the exchangeable $\mathrm{K}$ content at both depths $(0$ to $15 \mathrm{~cm}$ and 15 to $30 \mathrm{~cm}$ ) of Satkhira range was ranged between 1.19 to $2.02 \mathrm{meq} / 100 \mathrm{~g}$ and 1.3 to 2.12 meq/100g, respectively (Table 3 ). It was observed that the average value of exchangeable $K$ was comparatively higher in Satkhira forest range than that of in Khulna forest range at both soil layers (Table 3 ). The results also showed that the average (mean of two locations) exchangeable $\mathrm{K}$ value of mangrove forest of Sundarbans was higher in sub-surface soil (1.55 $\mathrm{meq} / 100 \mathrm{~g})$ and lower $(1.33 \mathrm{meq} / 100 \mathrm{~g})$ in surface soil (Table 6). This higher content of $\mathrm{K}$ in sub-surface soil might be due to alleviation process (Sadiqul Amin, 2016). Muhibbullah et al. (2005), Ramamurthy et al. (2012), Hossain et al. (2012) and Hossain and Bhuiyan (2015) conducted studies on the nutrient status of Sundarbans mangrove forest soil and they found similar results which were supported to the present findings.

\section{Secondary nutrients ( $\mathrm{Ca}, \mathrm{Mg}, \mathrm{S}$ )}

The results of Table 4 showed that the amount of available $\mathrm{Ca}$ in surface and sub-surface soils of Khulna 
Table 2. The status of $\mathrm{pH}$ and $\mathrm{OM}$ in surface and sub-surface soils of Khulna and Satkhira ranges of the Sundarbans mangrove forest of Bangladesh.

\begin{tabular}{|c|c|c|c|c|c|c|c|c|c|}
\hline \multirow{3}{*}{$\begin{array}{l}\text { Sites } \\
\text { No. }\end{array}$} & \multicolumn{4}{|c|}{ Khulna Range } & \multirow{3}{*}{$\begin{array}{l}\text { Sites } \\
\text { No. }\end{array}$} & \multicolumn{4}{|c|}{ Satkhira Range } \\
\hline & \multicolumn{2}{|c|}{$\mathrm{pH}$} & \multicolumn{2}{|c|}{ OM (\%) } & & \multicolumn{2}{|c|}{$\mathrm{pH}$} & \multicolumn{2}{|c|}{ OM (\%) } \\
\hline & SS & SSS & SS & SSS & & SS & SSS & SS & SSS \\
\hline $\mathrm{S}_{1}$ & 7.64 & 7.46 & 1.71 & 1.51 & $\mathrm{~S}_{24}$ & 7.48 & 7.66 & 1.58 & 1.31 \\
\hline $\mathrm{S}_{2}$ & 7.79 & 7.62 & 1.56 & 1.58 & $\mathrm{~S}_{25}$ & 7.72 & 7.72 & 1.31 & 1.51 \\
\hline $\mathrm{S}_{3}$ & 7.49 & 7.1 & 1.84 & 1.84 & $\mathrm{~S}_{26}$ & 7.8 & 7.42 & 1.38 & 1.31 \\
\hline $\mathrm{S}_{4}$ & 7.47 & 7.54 & 1.51 & 1.31 & $\mathrm{~S}_{27}$ & 7.75 & 7.64 & 1.84 & 1.25 \\
\hline $\mathrm{S}_{5}$ & 7.64 & 7.34 & 1.25 & 1.25 & $\mathrm{~S}_{28}$ & 7.81 & 7.52 & 2.04 & 1.58 \\
\hline $\mathrm{S}_{6}$ & 7.49 & 7.49 & 1.31 & 1.31 & $\mathrm{~S}_{29}$ & 7.48 & 7.49 & 1.91 & 1.38 \\
\hline $\mathrm{S}_{7}$ & 7.49 & 7.39 & 1.38 & 1.31 & $\mathrm{~S}_{30}$ & 7.72 & 7.59 & 1.38 & 1.38 \\
\hline $\mathrm{S}_{8}$ & 7.59 & 7.65 & 1.25 & 1.25 & $\mathrm{~S}_{31}$ & 7.78 & 7.55 & 1.58 & 1.18 \\
\hline $\mathrm{S}_{9}$ & 7.44 & 7.5 & 1.97 & 1.25 & $\mathrm{~S}_{32}$ & 7.78 & 7.84 & 1.51 & 1.71 \\
\hline$S_{10}$ & 7.43 & 7.82 & 1.38 & 1.58 & $\mathrm{~S}_{33}$ & 7.84 & 7.84 & 2.04 & 1.84 \\
\hline$S_{11}$ & 7.56 & 7.46 & 1.38 & 1.51 & $\mathrm{~S}_{34}$ & 7.71 & 7.48 & 1.58 & 1.51 \\
\hline$S_{12}$ & 7.47 & 7.48 & 1.97 & 1.31 & $\mathrm{~S}_{35}$ & 7.67 & 7.46 & 1.97 & 1.31 \\
\hline$S_{13}$ & 7.52 & 7.7 & 1.25 & 1.31 & $\mathrm{~S}_{36}$ & 7.55 & 7.75 & 1.84 & 1.43 \\
\hline$S_{14}$ & 7.63 & 7.58 & 1.84 & 1.31 & $\mathrm{~S}_{37}$ & 7.67 & 7.66 & 1.51 & 1.51 \\
\hline $\mathrm{S}_{15}$ & 7.22 & 7.42 & 1.91 & 1.12 & $\mathrm{~S}_{38}$ & 7.3 & 7.52 & 1.58 & 1.38 \\
\hline$S_{16}$ & 7.46 & 7.56 & 1.58 & 1.31 & $\mathrm{~S}_{39}$ & 7.74 & 7.56 & 1.58 & 1.51 \\
\hline$S_{17}$ & 7.36 & 7.48 & 1.97 & 1.12 & $\mathrm{~S}_{40}$ & 7.76 & 7.68 & 1.68 & 1.42 \\
\hline$S_{18}$ & 7.89 & 7.75 & 1.38 & 1.51 & $\mathrm{~S}_{41}$ & 7.73 & 7.85 & 1.58 & 1.56 \\
\hline$S_{19}$ & 7.52 & 7.34 & 1.91 & 1.84 & $\mathrm{~S}_{42}$ & 7.69 & 7.67 & 1.68 & 1.59 \\
\hline $\mathrm{S}_{20}$ & 7.58 & 7.44 & 1.15 & 1.12 & $\mathrm{~S}_{43}$ & 7.59 & 7.74 & 1.71 & 1.6 \\
\hline$S_{21}$ & 7.92 & 7.24 & 1.91 & 1.18 & $\mathrm{~S}_{44}$ & 7.96 & 7.64 & 1.97 & 1.78 \\
\hline $\mathrm{S}_{22}$ & 7.86 & 7.18 & 1.84 & 1.67 & $\mathrm{~S}_{45}$ & 7.76 & 7.18 & 1.83 & 1.67 \\
\hline \multirow[t]{2}{*}{$\mathrm{S}_{23}$} & 7.63 & 7.62 & 1.86 & 1.43 & $\mathrm{~S}_{46}$ & 7.82 & 7.76 & 1.76 & 1.78 \\
\hline & 7.22 & 7.10 & 1.15 & 1.12 & & 7.30 & 7.18 & 1.58 & 1.18 \\
\hline \multirow[t]{2}{*}{ Range } & to & to & to & to & Range & to & to & to & to \\
\hline & 7.92 & 7.82 & 1.97 & 1.84 & & 7.96 & 7.86 & 2.04 & 1.84 \\
\hline Mean & 7.57 & 7.49 & 1.61 & 1.39 & Mean & 7.70 & 7.62 & 1.69 & 1.50 \\
\hline $\mathrm{Sd}$ & 0.17 & 0.175 & 0.29 & 0.21 & $\mathrm{Sd}$ & 0.14 & 0.157 & 0.21 & 0.18 \\
\hline CV\% & 2.2 & 2.3 & 17.8 & 15.1 & $\mathrm{CV} \%$ & 1.8 & 2.1 & 12.6 & 11.9 \\
\hline
\end{tabular}

$\mathrm{S}=$ Soil sample sites, $\mathrm{SS}=$ Surface soil $(0-15 \mathrm{~cm}), \mathrm{SSS}=$ Subsurface soil $(15-30 \mathrm{~cm})$.

range of Sundarbans mangrove forest varied from 6.1 to $16.9 \mathrm{meq} / 100 \mathrm{ml}$ and 5 to $14 \mathrm{meq} / 100 \mathrm{ml}$, respectively. Accordingly, in Satkhira range the amount of available $\mathrm{Ca}$ in surface and sub-surface soils varied from 2.4 to $9.8 \mathrm{meq} / 100 \mathrm{ml}$ and 2.3 to $8.9 \mathrm{meq} / 100 \mathrm{ml}$, respectively (Table 4 ). In the case of available $\mathrm{Mg}$, the amount ranged from 2.0 to $4.9 \mathrm{meq} / 100 \mathrm{ml}$ at 0 to $15 \mathrm{~cm}$ soil depth and 1.7 to $4.3 \mathrm{meq} / 100 \mathrm{ml}$ at a 15 to $30 \mathrm{~cm}$ soil depth of Khulna range (Table 4). While in Satkhira range the amount of available $\mathrm{Mg}$ ranged from 0.9 to 3.2 $\mathrm{meq} / 100 \mathrm{ml}$ at 0 to $15 \mathrm{~cm}$ soil depth and 0.84 to 3.0 $\mathrm{meq} / 100 \mathrm{ml}$ at 15 to $30 \mathrm{~cm}$ soil depth (Table 4). The result also showed that the amount of available $S$ in surface and sub-surface soils of Sundarbans mangrove forest varied from 100.88 to $232.65 \mathrm{ppm}$ and 84.41 to 208.53 ppm, respectively in the Khulna range (Table 4).
On the other hand, the values of available $S$ in surface and sub-surface soils of Satkhira range varied from 114.12 to $233.23 \mathrm{ppm}$ and 76.18 to $230 \mathrm{ppm}$, respectively (Table 4). From Table 6 it was observed that the average values of available $\mathrm{Ca}, \mathrm{Mg}$ and $\mathrm{S}$ were higher in surface soils than sub-surface soils of Sundarbans mangrove forest. Maniruzzarnan et al. (2009) and Ramamurthy et al. (2012) also found high Ca and $\mathrm{Mg}$ content in soils of Sundarbans mangrove forest which was very supportive of the present study. Maniruzzarnan et al. (2009) found that the available S content in surface and sub-surface soils of mangrove forest of Bangladesh varied between 152.43 to $335.35 \mathrm{mg}$ $\mathrm{kg}^{-1}$ and 101.62 to $223.57 \mathrm{mg} \mathrm{kg}^{-1}$ with their mean values of 225.51 and $162.05 \mathrm{mg} \mathrm{kg}^{-1}$, respectively which is in agreement with the present study result. 
Table 3. The status of primary macronutrients $(N, P, K)$ in surface and sub-surface soils of Khulna and Satkhira ranges of the Sundarbans mangrove forest of Bangladesh.

\begin{tabular}{|c|c|c|c|c|c|c|c|c|c|c|c|c|c|}
\hline \multirow{3}{*}{$\begin{array}{l}\text { Sites } \\
\text { No. }\end{array}$} & \multicolumn{6}{|c|}{ Khulna Range } & \multirow{3}{*}{$\begin{array}{l}\text { Sites } \\
\text { No. }\end{array}$} & \multicolumn{6}{|c|}{ Satkhira Range } \\
\hline & \multicolumn{2}{|c|}{$\begin{array}{l}N \\
(\%)\end{array}$} & \multicolumn{2}{|c|}{$\begin{array}{c}\mathbf{P} \\
(\mathrm{ppm})\end{array}$} & \multicolumn{2}{|c|}{$\begin{array}{c}\mathrm{K} \\
(\mathrm{meq} / 100 \mathrm{~g})\end{array}$} & & \multicolumn{2}{|c|}{$\begin{array}{c}\mathrm{N} \\
(\%)\end{array}$} & \multicolumn{2}{|c|}{$\begin{array}{c}\mathbf{P} \\
(\mathrm{ppm})\end{array}$} & \multicolumn{2}{|c|}{$\begin{array}{c}\mathrm{K} \\
(\mathrm{meq} / 100 \mathrm{~g})\end{array}$} \\
\hline & SS & SSS & SS & SS & SS & SSS & & SS & SSS & SS & SSS & SS & SSS \\
\hline $\mathrm{S}_{1}$ & 0.08 & 0.07 & 18.03 & 18.03 & 0.62 & 1.19 & $\mathrm{~S}_{24}$ & 0.08 & 0.07 & 14.80 & 19.39 & 1.29 & 1.45 \\
\hline $\mathrm{S}_{2}$ & 0.08 & 0.08 & 20.41 & 20.58 & 0.72 & 1.24 & $\mathrm{~S}_{25}$ & 0.07 & 0.08 & 16.16 & 21.94 & 1.24 & 1.91 \\
\hline $\mathrm{S}_{3}$ & 0.09 & 0.09 & 20.24 & 21.26 & 0.82 & 1.45 & $\mathrm{~S}_{26}$ & 0.07 & 0.06 & 13.61 & 15.65 & 1.19 & 1.35 \\
\hline $\mathrm{S}_{4}$ & 0.07 & 0.06 & 18.37 & 20.75 & 0.67 & 0.93 & $\mathrm{~S}_{27}$ & 0.09 & 0.06 & 18.03 & 16.50 & 1.40 & 1.30 \\
\hline $\mathrm{S}_{5}$ & 0.20 & 0.06 & 17.18 & 15.31 & 0.82 & 0.82 & $\mathrm{~S}_{28}$ & 0.11 & 0.07 & 21.26 & 20.50 & 1.76 & 1.55 \\
\hline $\mathrm{S}_{6}$ & 0.07 & 0.07 & 17.35 & 19.56 & 0.57 & 0.88 & $\mathrm{~S}_{29}$ & 0.10 & 0.07 & 15.82 & 17.63 & 1.55 & 1.55 \\
\hline $\mathrm{S}_{7}$ & 0.07 & 0.07 & 17.35 & 17.69 & 0.78 & 1.03 & $\mathrm{~S}_{30}$ & 0.07 & 0.07 & 17.35 & 20.75 & 1.91 & 1.50 \\
\hline $\mathrm{S}_{8}$ & 0.06 & 0.07 & 21.26 & 18.35 & 1.03 & 1.19 & $\mathrm{~S}_{31}$ & 0.07 & 0.05 & 14.12 & 17.69 & 1.24 & 1.50 \\
\hline $\mathrm{S}_{9}$ & 0.07 & 0.06 & 20.24 & 17.69 & 1.03 & 1.14 & $\mathrm{~S}_{32}$ & 0.08 & 0.08 & 17.18 & 17.63 & 1.55 & 1.97 \\
\hline$S_{10}$ & 0.07 & 0.08 & 19.73 & 19.46 & 1.19 & 1.55 & $\mathrm{~S}_{33}$ & 0.08 & 0.10 & 17.69 & 18.54 & 1.71 & 1.86 \\
\hline$S_{11}$ & 0.07 & 0.08 & 23.99 & 22.63 & 1.24 & 1.29 & $\mathrm{~S}_{34}$ & 0.11 & 0.08 & 17.52 & 17.63 & 1.66 & 2.02 \\
\hline$S_{12}$ & 0.07 & 0.06 & 19.05 & 21.94 & 1.29 & 1.19 & $\mathrm{~S}_{35}$ & 0.08 & 0.06 & 20.75 & 18.37 & 1.40 & 1.76 \\
\hline$S_{13}$ & 0.06 & 0.07 & 19.05 & 18.31 & 1.00 & 1.35 & $\mathrm{~S}_{36}$ & 0.11 & 0.07 & 24.50 & 19.49 & 2.02 & 2.12 \\
\hline$S_{14}$ & 0.10 & 0.06 & 21.09 & 22.29 & 1.29 & 1.71 & $S_{37}$ & 0.09 & 0.07 & 21.94 & 18.37 & 1.81 & 1.71 \\
\hline$S_{15}$ & 0.10 & 0.05 & 28.07 & 15.31 & 1.19 & 1.45 & $\mathrm{~S}_{38}$ & 0.22 & 0.07 & 18.37 & 18.54 & 1.24 & 1.71 \\
\hline$S_{16}$ & 0.08 & 0.06 & 21.09 & 20.07 & 1.45 & 1.60 & $\mathrm{~S}_{39}$ & 0.08 & 0.08 & 23.31 & 20.65 & 1.55 & 1.76 \\
\hline$S_{17}$ & 0.07 & 0.05 & 17.35 & 14.80 & 1.35 & 1.60 & $\mathrm{~S}_{40}$ & 0.08 & 0.06 & 16.79 & 17.64 & 1.71 & 1.86 \\
\hline$S_{18}$ & 0.07 & 0.07 & 21.35 & 20.07 & 1.45 & 1.66 & $S_{41}$ & 0.07 & 0.08 & 18.72 & 19.63 & 1.66 & 2.02 \\
\hline$S_{19}$ & 0.10 & 0.10 & 21.09 & 20.01 & 1.09 & 1.50 & $\mathrm{~S}_{42}$ & 0.09 & 0.06 & 21.65 & 19.47 & 1.48 & 1.86 \\
\hline $\mathrm{S}_{20}$ & 0.07 & 0.05 & 19.02 & 20.75 & 1.29 & 1.45 & $\mathrm{~S}_{43}$ & 0.09 & 0.05 & 22.50 & 19.69 & 2.01 & 1.98 \\
\hline $\mathrm{S}_{21}$ & 0.09 & 0.05 & 17.86 & 17.66 & 0.98 & 1.66 & $\mathrm{~S}_{44}$ & 0.08 & 0.06 & 20.94 & 19.47 & 1.87 & 1.79 \\
\hline$S_{22}$ & 0.10 & 0.11 & 16.50 & 18.54 & 1.60 & 1.66 & $\mathrm{~S}_{45}$ & 0.11 & 0.07 & 20.27 & 19.44 & 1.38 & 1.78 \\
\hline $\mathrm{S}_{23}$ & 0.08 & 0.06 & 17.76 & 17.65 & 1.45 & 1.47 & $S_{46}$ & 0.07 & 0.06 & 19.31 & 18.85 & 1.57 & 1.87 \\
\hline Ran & $\begin{array}{c}0.06 \\
\text { to } \\
0.20\end{array}$ & $\begin{array}{c}0.05 \\
\text { to } \\
0.11\end{array}$ & $\begin{array}{c}16.5 \\
\text { to } \\
28.07\end{array}$ & $\begin{array}{c}14.8 \\
\text { to } \\
22.63\end{array}$ & $\begin{array}{c}0.57 \\
\text { to } \\
1.60\end{array}$ & $\begin{array}{c}0.82 \\
\text { to } \\
1.71\end{array}$ & ye & $\begin{array}{c}0.07 \\
\text { to } \\
0.22\end{array}$ & $\begin{array}{c}0.05 \\
\text { to } \\
0.10\end{array}$ & $\begin{array}{c}13.61 \\
\text { to } \\
24.50\end{array}$ & $\begin{array}{l}15.65 \\
\text { to } \\
21.94\end{array}$ & $\begin{array}{c}1.19 \\
\text { to } \\
2.02\end{array}$ & $\begin{array}{c}1.30 \\
\text { to } \\
2.12\end{array}$ \\
\hline Mean & 0.08 & 0.07 & 19.71 & 19.07 & 1.08 & 1.35 & Mean & 0.09 & 0.069 & 18.81 & 18.85 & 1.57 & 1.75 \\
\hline $\mathrm{Sd}$ & 0.03 & 0.016 & 2.58 & 2.17 & 0.30 & 0.27 & $\mathrm{Sd}$ & 0.03 & 0.011 & 2.97 & 1.45 & 0.25 & 0.23 \\
\hline CV\% & 34.0 & 22.9 & 13.1 & 11.4 & 27.5 & 19.8 & CV\% & 34.4 & 16.6 & 15.8 & 7.7 & 16.0 & 12.9 \\
\hline
\end{tabular}

S = Soil sample sites, $S S=$ Surface soil $(0-15 \mathrm{~cm})$, SSS = Subsurface soil $(15-30 \mathrm{~cm})$.

\section{Status of soil micronutrients (Fe, B, Zn)}

The result showed that the available Fe content of surface and sub-surface soils ranged from 17 to 27 $\mu \mathrm{g} / \mathrm{ml}$ and 14 to $22 \mu \mathrm{g} / \mathrm{ml}$ and the calculated mean values were 22.65 and $19.04 \mu \mathrm{g} / \mathrm{ml}$, respectively in Khulna range of Sundarbans mangrove forest of Bangladesh (Table 5). While the available Fe content of surface and subsurface soils ranged from 14 to $31 \mu \mathrm{g} / \mathrm{ml}$ and 13 to 25 $\mu \mathrm{g} / \mathrm{ml}$, respectively in Satkhira range. However, the calculated mean values of available Fe were 22.78 and $19.70 \mu \mathrm{g} / \mathrm{ml}$, respectively in Satkhira range of Sundarbans mangrove forest (Table 5). In the case of available B content, the values in surface and subsurface soils ranged from 0.10 to $0.76 \mu \mathrm{g} / \mathrm{ml}$ and 0.32 to $0.70 \mu \mathrm{g} / \mathrm{ml}$, respectively in Khulna range. The calculated mean value of available B was noted as 0.63 $\mu \mathrm{g} / \mathrm{ml}$ in surface and $0.59 \mu \mathrm{g} / \mathrm{ml}$ in sub-surface soils of Khulna range in Sundarbans mangrove forest (Table 5). Similarly, In Satkhira range the available B content of surface and sub-surface soils varied from 0.54 to 0.75 $\mu \mathrm{g} / \mathrm{ml}$ and 0.46 to $0.70 \mu \mathrm{g} / \mathrm{ml}$ and the calculated mean values were 0.69 and $0.64 \mu \mathrm{g} / \mathrm{ml}$, respectively (Table 5). The surface and sub-surface soils in Khulna range of the mangrove forest of Sundarbans contained the available $\mathrm{Zn}$ ranged from 3.0 to $9.16 \mu \mathrm{g} / \mathrm{ml}$ and 2.64 to $7.88 \mu \mathrm{g} / \mathrm{ml}$, respectively. The calculated mean value of available $\mathrm{Zn}$ was $5.77 \mu \mathrm{g} / \mathrm{ml}$ in surface soil and $4.95 \mu \mathrm{g} / \mathrm{ml}$ in subsurface soil in Khulna range. Accordingly, the available $\mathrm{Zn}$ content of surface and sub-surface soils ranged from 
Table 4. The status of secondary macronutrients $(\mathrm{Ca}, \mathrm{Mg}, \mathrm{S})$ in surface and sub-surface soils of Khulna and Satkhira ranges of the Sundarbans mangrove forest of Bangladesh.

\begin{tabular}{|c|c|c|c|c|c|c|c|c|c|c|c|c|c|}
\hline \multirow{3}{*}{$\begin{array}{l}\text { Sites } \\
\text { No. }\end{array}$} & \multicolumn{6}{|c|}{ Khulna Range } & \multirow{3}{*}{$\begin{array}{l}\text { Sites } \\
\text { No. }\end{array}$} & \multicolumn{6}{|c|}{ Satkhira Range } \\
\hline & \multicolumn{2}{|c|}{$\begin{array}{c}\mathrm{Ca} \\
(\mathrm{meq} / 100 \mathrm{ml})\end{array}$} & \multicolumn{2}{|c|}{$\begin{array}{c}\mathrm{Mg} \\
(\mathrm{meq} / 100 \mathrm{ml})\end{array}$} & \multicolumn{2}{|c|}{$\begin{array}{c}\mathrm{S} \\
(\mathrm{ppm})\end{array}$} & & \multicolumn{2}{|c|}{$\begin{array}{c}\mathrm{Ca} \\
(\mathrm{meq} / 100 \mathrm{ml})\end{array}$} & \multicolumn{2}{|c|}{$\begin{array}{c}\mathrm{Mg} \\
(\mathrm{meq} / 100 \mathrm{ml})\end{array}$} & \multicolumn{2}{|c|}{$\begin{array}{c}\mathrm{S} \\
(\mathrm{ppm})\end{array}$} \\
\hline & SS & SSS & SS & SSS & SS & SSS & & SS & SSS & SS & SSS & SS & SSS \\
\hline $\mathrm{S}_{1}$ & 16.5 & 12.4 & 4.8 & 4.0 & 177.65 & 174.71 & $\mathrm{~S}_{24}$ & 4.0 & 3.8 & 1.4 & 1.3 & 126.76 & 122.06 \\
\hline $\mathrm{S}_{2}$ & 13.1 & 11.3 & 4.1 & 4.0 & 165.59 & 84.41 & $\mathrm{~S}_{25}$ & 3.2 & 3.0 & 1.2 & 1.1 & 136.76 & 160.29 \\
\hline $\mathrm{S}_{3}$ & 13.5 & 11.2 & 4.1 & 3.9 & 126.18 & 156.76 & $\mathrm{~S}_{26}$ & 5.5 & 5.1 & 1.8 & 1.7 & 169.12 & 76.18 \\
\hline $\mathrm{S}_{4}$ & 16.9 & 14.0 & 4.8 & 4.2 & 232.65 & 119.12 & $\mathrm{~S}_{27}$ & 4.3 & 4.0 & 1.5 & 1.4 & 233.23 & 90.29 \\
\hline $\mathrm{S}_{5}$ & 14.5 & 13.0 & 4.3 & 4.2 & 167.65 & 186.47 & $\mathrm{~S}_{28}$ & 6.9 & 6.2 & 2.4 & 2.1 & 120.29 & 89.12 \\
\hline $\mathrm{S}_{6}$ & 14.1 & 11.6 & 4.3 & 4.0 & 151.76 & 140.59 & $\mathrm{~S}_{29}$ & 3.5 & 3.4 & 1.2 & 1.2 & 202.94 & 208.53 \\
\hline $\mathrm{S}_{7}$ & 15.1 & 13.6 & 4.6 & 4.3 & 146.76 & 161.47 & $\mathrm{~S}_{30}$ & 7.1 & 6.6 & 2.4 & 2.3 & 115.29 & 130.59 \\
\hline $\mathrm{S}_{8}$ & 16.9 & 13.3 & 4.9 & 4.3 & 147.35 & 125.00 & $\mathrm{~S}_{31}$ & 5.8 & 5.2 & 2.0 & 1.8 & 114.12 & 172.06 \\
\hline $\mathrm{S}_{9}$ & 15.2 & 12.3 & 4.7 & 4.1 & 232.42 & 165.00 & $\mathrm{~S}_{32}$ & 4.5 & 4.0 & 1.6 & 1.4 & 133.23 & 195.71 \\
\hline$S_{10}$ & 14.6 & 12.1 & 4.3 & 4.1 & 150.59 & 208.53 & $\mathrm{~S}_{33}$ & 4.0 & 3.8 & 1.3 & 1.3 & 212.06 & 155.00 \\
\hline$S_{11}$ & 15.0 & 12.6 & 4.5 & 4.1 & 179.41 & 160.00 & $\mathrm{~S}_{34}$ & 2.4 & 2.3 & 0.9 & 0.8 & 148.82 & 178.23 \\
\hline$S_{12}$ & 14.9 & 11.1 & 4.4 & 4.0 & 216.18 & 168.23 & $\mathrm{~S}_{35}$ & 5.0 & 5.1 & 1.7 & 1.7 & 133.23 & 230.00 \\
\hline$S_{13}$ & 13.4 & 11.1 & 4.1 & 3.5 & 216.18 & 180.00 & $\mathrm{~S}_{36}$ & 4.4 & 4.2 & 1.5 & 1.4 & 230.88 & 208.53 \\
\hline$S_{14}$ & 13.8 & 11.1 & 4.3 & 4.0 & 169.12 & 177.65 & $\mathrm{~S}_{37}$ & 9.8 & 8.9 & 3.2 & 3.0 & 201.76 & 173.82 \\
\hline$S_{15}$ & 6.1 & 5.0 & 2.0 & 1.7 & 100.88 & 126.47 & $\mathrm{~S}_{38}$ & 4.6 & 4.3 & 1.6 & 1.4 & 127.03 & 186.76 \\
\hline$S_{16}$ & 6.7 & 6.1 & 2.3 & 2.1 & 118.82 & 171.47 & $\mathrm{~S}_{39}$ & 6.4 & 6.1 & 2.2 & 2.0 & 208.53 & 194.71 \\
\hline$S_{17}$ & 9.6 & 8.5 & 3.1 & 3.0 & 180.29 & 137.35 & $\mathrm{~S}_{40}$ & 4.2 & 3.9 & 1.4 & 1.5 & 202.66 & 165.80 \\
\hline$S_{18}$ & 13.4 & 11.1 & 4.1 & 3.5 & 204.41 & 130.69 & $S_{41}$ & 3.4 & 3.3 & 1.9 & 1.8 & 168.82 & 178.23 \\
\hline$S_{19}$ & 10.9 & 9.8 & 3.4 & 3.1 & 125.00 & 166.76 & $\mathrm{~S}_{42}$ & 5.2 & 5.6 & 1.6 & 1.9 & 123.23 & 203.70 \\
\hline $\mathrm{S}_{20}$ & 11.1 & 10.4 & 3.3 & 3.2 & 201.47 & 159.12 & $\mathrm{~S}_{43}$ & 4.9 & 3.2 & 1.7 & 1.6 & 223.98 & 205.53 \\
\hline $\mathrm{S}_{21}$ & 13.1 & 12.3 & 4.1 & 4.0 & 170.59 & 108.82 & $\mathrm{~S}_{44}$ & 8.8 & 6.8 & 3.1 & 2.9 & 199.76 & 185.82 \\
\hline$S_{22}$ & 9.6 & 9.0 & 3.5 & 3.1 & 156.47 & 132.35 & $\mathrm{~S}_{45}$ & 4.7 & 4.5 & 1.8 & 1.6 & 137.03 & 196.76 \\
\hline \multirow[t]{2}{*}{$\mathrm{S}_{23}$} & 11.5 & 9.8 & 4.1 & 4.3 & 185.65 & 138.76 & $\mathrm{~S}_{46}$ & 6.8 & 6.6 & 2.6 & 1.9 & 208.53 & 198.71 \\
\hline & 6.10 & 5.0 & 2.0 & 1.7 & 100.88 & 84.41 & & 2.4 & 2.3 & 0.9 & 0.8 & 114.12 & 76.18 \\
\hline \multirow[t]{2}{*}{ Range } & to & to & to & to & to & to & Range & to & to & to & to & $\begin{array}{l}\text { to } \\
\text { to }\end{array}$ & to \\
\hline & 16.9 & 14.0 & 4.9 & 4.3 & 232.65 & 208.53 & & 9.8 & 8.9 & 3.2 & 3.0 & 233.23 & 230 \\
\hline Mean & 13.02 & 10.99 & 4.00 & 3.68 & 170.57 & 151.29 & Mean & 5.19 & 4.78 & 1.83 & 1.70 & 168.61 & 169.84 \\
\hline $\mathrm{Sd}$ & 2.92 & 2.22 & 0.76 & 0.70 & 35.72 & 28.48 & $\mathrm{Sd}$ & 1.78 & 1.55 & 0.59 & 0.52 & 42.21 & 41.75 \\
\hline CV\% & 22.4 & 20.2 & 18.9 & 19.0 & 20.9 & 18.8 & CV\% & 34.3 & 32.5 & 32.2 & 30.7 & 25.0 & 24.6 \\
\hline
\end{tabular}

$\mathrm{S}=$ Soil sample sites, $\mathrm{SS}=$ Surface soil $(0-15 \mathrm{~cm})$, SSS = Subsurface soil $(15-30 \mathrm{~cm})$.

1.01 to $9.23 \mu \mathrm{g} / \mathrm{ml}$ and 1.1 to $8.51 \mu \mathrm{g} / \mathrm{ml}$ and the calculated mean values were 2.67 and $2.29 \mu \mathrm{g} / \mathrm{ml}$, respectively in Satkhira range of Sundarbans mangrove forest (Table 5). From the results of Table 6, it was observed that the average values (mean of two locations) of available $\mathrm{Fe}, \mathrm{B}$, and $\mathrm{Zn}$ were comparatively higher in surface soils than sub-surface soils of Sundarbans mangrove forest. Maniruzzarnan et al. (2009), Ramamurthy et al. (2012), Rao and Rao (2014) and Hasan et al. (2016) conducted various studies on Sundarbans soils and found similar results in case of available $\mathrm{Fe}, \mathrm{B}$, and $\mathrm{Zn}$ which was very much supportive to present findings.

\section{Tree stands density of the study area}

The result of Table 7 revealed that in the selected sites of Khulna range, a total of 84 trees were found in all (10 $\mathrm{m} \times 10 \mathrm{~m}$ ) quadrate samples with an average number of 5 trees/plot and an average stand density 525 (trees/ha) (Table 7). Accordingly, the selected sites of Satkhira range, a total of 91 trees were recorded with an average number of 6 trees/plot and an average stand density 569 (trees/ha) (Table 7). Joshi and Ghose (2014) conducted a study on community structure, species diversity, and above ground biomass of the Sundarbans mangrove swamps and found that the density of trees with $\mathrm{dbh} \geq 10 \mathrm{~cm}$ to be 556 trees/ha and 498 trees/ha in Coastal Avicennia alba community and Tidal Avicennia marina community, respectively which was closed to the present study result. Hossain et al. (2013), Mamun et al. (2015) and Hossain et al. (2015) also found a very close result for the different forest of Bangladesh which was supportive to the present study. 
Table 5. The status of micronutrients ( $\mathrm{Fe}, \mathrm{B}$ and $\mathrm{Zn})$ in surface and sub-surface soils of Khulna and Satkhira ranges of the Sundarbans mangrove forest of Bangladesh.

\begin{tabular}{|c|c|c|c|c|c|c|c|c|c|c|c|c|c|}
\hline \multirow{3}{*}{$\begin{array}{l}\text { Sites } \\
\text { No. }\end{array}$} & \multicolumn{6}{|c|}{ Khulna Range } & \multirow{3}{*}{$\begin{array}{l}\text { Sites } \\
\text { No. }\end{array}$} & \multicolumn{6}{|c|}{ Satkhira Range } \\
\hline & \multicolumn{2}{|c|}{$\begin{array}{c}\mathrm{Fe} \\
(\mu \mathrm{g} / \mathrm{ml})\end{array}$} & \multicolumn{2}{|c|}{$\begin{array}{c}\text { B } \\
(\mu \mathrm{g} / \mathrm{ml})\end{array}$} & \multicolumn{2}{|c|}{$\begin{array}{c}\mathrm{Zn} \\
(\mu \mathrm{g} / \mathrm{ml})\end{array}$} & & \multicolumn{2}{|c|}{$\begin{array}{c}\mathrm{Fe} \\
(\mu \mathrm{g} / \mathrm{ml})\end{array}$} & \multicolumn{2}{|c|}{$\begin{array}{c}\text { B } \\
(\mu \mathrm{g} / \mathrm{ml})\end{array}$} & \multicolumn{2}{|c|}{$\begin{array}{c}\mathrm{Zn} \\
(\mu \mathrm{g} / \mathrm{ml})\end{array}$} \\
\hline & SS & sss & SS & SSS & SS & SSS & & SS & SSS & SS & SSS & SS & SSS \\
\hline $\mathrm{S}_{1}$ & 23.0 & 19.0 & 0.58 & 0.54 & 6.72 & 5.29 & $\mathrm{~S}_{24}$ & 19.0 & 20.0 & 0.54 & 0.52 & 1.17 & 1.22 \\
\hline $\mathrm{S}_{2}$ & 25.0 & 21.0 & 0.64 & 0.60 & 8.55 & 7.23 & $\mathrm{~S}_{25}$ & 15.0 & 15.0 & 0.58 & 0.48 & 1.13 & 1.15 \\
\hline $\mathrm{S}_{3}$ & 25.0 & 20.0 & 0.72 & 0.66 & 3.00 & 2.64 & $\mathrm{~S}_{26}$ & 15.0 & 13.0 & 0.68 & 0.62 & 2.06 & 1.80 \\
\hline $\mathrm{S}_{4}$ & 21.0 & 18.0 & 0.62 & 0.60 & 9.16 & 7.88 & $\mathrm{~S}_{27}$ & 14.0 & 15.0 & 0.62 & 0.60 & 1.01 & 1.10 \\
\hline $\mathrm{S}_{5}$ & 24.0 & 20.0 & 0.48 & 0.42 & 8.42 & 7.14 & $\mathrm{~S}_{28}$ & 26.0 & 21.0 & 0.74 & 0.70 & 3.27 & 2.64 \\
\hline $\mathrm{S}_{6}$ & 22.0 & 17.0 & 0.64 & 0.58 & 7.52 & 6.23 & $\mathrm{~S}_{29}$ & 28.0 & 21.0 & 0.72 & 0.70 & 2.17 & 1.72 \\
\hline $\mathrm{S}_{7}$ & 24.0 & 20.0 & 0.54 & 0.52 & 4.22 & 3.94 & $\mathrm{~S}_{30}$ & 18.0 & 14.0 & 0.62 & 0.50 & 3.39 & 2.83 \\
\hline $\mathrm{S}_{8}$ & 23.0 & 19.0 & 0.62 & 0.56 & 3.46 & 3.01 & $\mathrm{~S}_{31}$ & 21.0 & 18.0 & 0.54 & 0.46 & 2.66 & 2.14 \\
\hline $\mathrm{S}_{9}$ & 23.0 & 20.0 & 0.70 & 0.66 & 6.49 & 5.28 & $\mathrm{~S}_{32}$ & 26.0 & 21.0 & 0.74 & 0.70 & 1.87 & 1.19 \\
\hline$S_{10}$ & 25.0 & 21.0 & 0.70 & 0.50 & 6.78 & 6.02 & $\mathrm{~S}_{33}$ & 19.0 & 15.0 & .75 & 0.66 & 1.23 & 1.10 \\
\hline$S_{11}$ & 23.0 & 20.0 & 0.75 & 0.70 & 6.72 & 5.98 & $\mathrm{~S}_{34}$ & 28.0 & 22.0 & 0.70 & 0.66 & 2.33 & 2.01 \\
\hline$S_{12}$ & 24.0 & 19.0 & 0.70 & 0.66 & 7.02 & 5.94 & $\mathrm{~S}_{35}$ & 25.0 & 23.0 & 0.70 & 0.66 & 2.09 & 1.88 \\
\hline$S_{13}$ & 17.0 & 15.0 & 0.70 & 0.68 & 3.39 & 3.00 & $\mathrm{~S}_{36}$ & 24.0 & 23.0 & 0.74 & 0.70 & 9.23 & 8.51 \\
\hline$S_{14}$ & 25.0 & 20.0 & 0.72 & 0.70 & 3.98 & 3.26 & $\mathrm{~S}_{37}$ & 21.0 & 20.0 & 0.72 & 0.68 & 1.70 & 1.10 \\
\hline$S_{15}$ & 21.0 & 19.0 & 0.76 & 0.70 & 4.54 & 4.15 & $\mathrm{~S}_{38}$ & 25.0 & 20.0 & 0.70 & 0.66 & 2.02 & 1.75 \\
\hline$S_{16}$ & 22.0 & 17.0 & 0.72 & 0.68 & 4.71 & 4.13 & $\mathrm{~S}_{39}$ & 31.0 & 24.0 & 0.72 & 0.68 & 3.96 & 3.11 \\
\hline$S_{17}$ & 23.0 & 19.0 & 0.70 & 0.66 & 4.79 & 4.29 & $\mathrm{~S}_{40}$ & 19.0 & 17.0 & 0.65 & 0.56 & 1.33 & 1.18 \\
\hline$S_{18}$ & 25.0 & 21.0 & 0.72 & 0.66 & 4.44 & 3.90 & $S_{41}$ & 27.0 & 25.0 & 0.73 & 0.66 & 2.35 & 2.08 \\
\hline$S_{19}$ & 20.0 & 14.0 & 0.72 & 0.70 & 5.99 & 5.20 & $\mathrm{~S}_{42}$ & 26.0 & 22.0 & 0.75 & 0.65 & 2.19 & 1.98 \\
\hline $\mathrm{S}_{20}$ & 17.0 & 16.0 & 0.74 & 0.70 & 3.16 & 2.84 & $\mathrm{~S}_{43}$ & 21.0 & 20.0 & 0.74 & 0.71 & 7.23 & 6.51 \\
\hline $\mathrm{S}_{21}$ & 24.0 & 20.0 & 0.10 & 0.40 & 8.26 & 7.20 & $\mathrm{~S}_{44}$ & 22.0 & 20.0 & 0.70 & 0.68 & 1.79 & 1.29 \\
\hline $\mathrm{S}_{22}$ & 27.0 & 22.0 & 0.44 & 0.32 & 5.74 & 4.83 & $\mathrm{~S}_{45}$ & 24.0 & 21.0 & 0.72 & 0.69 & 2.35 & 1.95 \\
\hline $\mathrm{S}_{23}$ & 18.0 & 21.0 & 0.46 & 0.34 & 5.67 & 4.38 & $\mathrm{~S}_{46}$ & 30.0 & 23.0 & 0.73 & 0.68 & 2.99 & 2.41 \\
\hline & 17 & 14 & 0.10 & 0.32 & 3.0 & 2.64 & & 14 & 13 & 0.5 & 0.46 & 1.01 & 1.1 \\
\hline Range & $\begin{array}{l}\text { to } \\
27\end{array}$ & $\begin{array}{l}\text { to } \\
22\end{array}$ & $\begin{array}{c}\text { to } \\
0.76\end{array}$ & $\begin{array}{c}\text { to } \\
0.70\end{array}$ & $\begin{array}{c}\text { to } \\
9.16\end{array}$ & $\begin{array}{c}\text { to } \\
7.88\end{array}$ & Range & $\begin{array}{l}\text { to } \\
31\end{array}$ & $\begin{array}{l}\text { to } \\
25\end{array}$ & $\begin{array}{c}\text { to } \\
0.75\end{array}$ & $\begin{array}{c}\text { to } \\
0.71\end{array}$ & $\begin{array}{c}\text { to } \\
9.23\end{array}$ & $\begin{array}{c}\text { to } \\
8.51\end{array}$ \\
\hline Mean & 22.65 & 19.04 & 0.63 & 0.59 & 5.77 & 4.95 & Mean & 22.78 & 19.70 & 0.69 & 0.64 & 2.67 & 2.29 \\
\hline $\mathrm{Sd}$ & 2.64 & 2.03 & 0.15 & 0.12 & 1.87 & 1.55 & $\mathrm{Sd}$ & 4.81 & 3.38 & 0.06 & 0.08 & 1.93 & 1.77 \\
\hline CV\% & 11.7 & 10.7 & 23.7 & 20.4 & 32.4 & 31.4 & CV\% & 21.1 & 17.1 & 9.4 & 12.1 & 72.2 & 77.4 \\
\hline
\end{tabular}

$\mathrm{S}=$ Soil sample sites, $\mathrm{SS}=$ Surface soil $(0-15 \mathrm{~cm})$, SSS = Subsurface soil $(15-30 \mathrm{~cm})$.

Table 6. Average values of $\mathrm{pH}, \mathrm{OM}, \mathrm{N}, \mathrm{P}, \mathrm{K}, \mathrm{Ca}, \mathrm{Mg}, \mathrm{S}, \mathrm{Fe}, \mathrm{B}$ and $\mathrm{Zn}$ status in surface and sub-surface soils of Sundarbans mangrove forest in Bangladesh.

\begin{tabular}{|c|c|c|c|c|c|c|c|c|c|c|c|}
\hline $\begin{array}{l}\text { Soil } \\
\text { depth }\end{array}$ & $\mathrm{pH}$ & OM & $\% \mathbf{N}$ & $\begin{array}{c}\mathbf{P} \\
(\mathbf{p p m})\end{array}$ & $\begin{array}{c}\mathrm{K} \\
(\mathrm{meq} / \\
100 \mathrm{~g})\end{array}$ & $\begin{array}{c}\mathrm{Ca} \\
(\mathrm{meq} / \\
100 \mathrm{ml})\end{array}$ & $\begin{array}{c}\begin{array}{c}\mathrm{Mg} \\
(\mathrm{meq} /\end{array} \\
100 \mathrm{ml})\end{array}$ & $\begin{array}{c}S \\
(p p m)\end{array}$ & $\begin{array}{c}\mathrm{Fe} \\
(\mu \mathrm{g} / \mathrm{ml})\end{array}$ & $\begin{array}{c}\text { B } \\
(\mu \mathrm{g} / \mathrm{ml})\end{array}$ & $\underset{(\mu \mathrm{g} / \mathrm{ml})}{\mathrm{Zn}}$ \\
\hline SS & 7.64 & 1.65 & 0.09 & 19.26 & 1.33 & 9.11 & 2.92 & 169.59 & 22.72 & 0.66 & 4.22 \\
\hline SSS & 7.56 & 1.45 & 0.07 & 18.96 & 1.55 & 7.89 & 2.69 & 160.57 & 19.37 & 0.62 & 3.62 \\
\hline
\end{tabular}

SS = Surface soil $(0-15 \mathrm{~cm})$, SSS = Subsurface soil $(15-30 \mathrm{~cm})$.

Table 7. Number of trees and stand density of Khulna and Satkhira ranges of the Sundarbans Mangrove forest in Bangladesh

\begin{tabular}{lcc}
\hline Forest Ranges & Average no. (trees/plot) & Stand density (trees/ha) \\
\hline Khulna & 5 & 525 \\
Satkhira & 6 & 569 \\
\hline
\end{tabular}




\section{Conclusion}

The results of this study indicated that the soil $\mathrm{pH}, \mathrm{OM}$, primary macronutrients $(\mathrm{N}, \mathrm{P}$ and $\mathrm{K})$, secondary macronutrients $(\mathrm{Ca}, \mathrm{Mg}$ and $\mathrm{S})$ and micronutrients $(\mathrm{Fe}$, $\mathrm{B}$ and $\mathrm{Zn}$ ) contents were observed comparatively higher in surface (0 to $15 \mathrm{~cm}$ depth) soils than sub-surface (15 to $30 \mathrm{~cm}$ depth) soils except exchangeable $\mathrm{K}$ of Sundarbans mangrove forest. Tree stand density result exhibits comparatively higher in Satkhira range than Khulna range, but the stand density is much lower than standard tree stand density. Human activities at present in Sundarbans mangrove forest are reducing the tree stand densities which ultimately affect the soil nutrient status. Therefore, the study suggests that increasing of the forest coverage might be prior need to conserve our natural forest as making appropriate tree stand density and improved soil fertility. The results of soil properties and tree stand density might be helped to researcher and policymaker for better understanding and management of Sundarbans.

\section{CONFLICT OF INTEREST}

The authors declare that they have no conflict of interest.

\section{ACKNOWLEDGEMENT}

We would like to express our appreciation to the Bangladesh Agricultural University Research System (BAURES), Bangladesh Agricultural University, Mymensingh, Bangladesh for funding this research.

\section{REFERENCES}

Arianto, C. L., Gandaseca, S., Rosli, N., Pazi, A. M. M., Ahmed, O. H., Hamid, H. A., \& Majid, N. M. A. (2015). Soil carbon storage in dominant species of Mangrove forest of Sarawak, Malaysia. International Journal of Physical Sciences, 10(6), 210-214.

Avery, T. E., \& Burkhart, H. E. (2002). Forest Measurement. 5th edition, McGraw Hill, New York. Pp. 144-167.

Awal, M. A. (2007). Analysis of possible environmental factors causing top-dying in mangrove forest trees in the Sundarbans in Bangladesh. Ph.D. Thesis, University of Bradford.

Bangladesh Forest Department (BFD) (2017). Ministry of Environment and Forests, Government of the People's Republic of Bangladesh, Forest Investment Programme, Dhaka, Bangladesh. Pp. 22-24.

Banglapedia (2012). The Sundarbans. 2nd Edition, National Encyclopedia of Bangladesh. Available at http://en.banglapedia.org/index.php?title=Sundarbans,_The

Barik, J., Mukhopadhyay, A., Ghosh, T., Mukhopadhyay, S.K., Chowdhury, S.M., \& Hazra, S. (2018). Mangrove species distribution and water salinity: An indicator species approach to Sundarbans. Journal of Coastal Conservation, 22(2), 361368.
Binkley, D. (1986). Forest nutrition management. New York, USA: Wiley-Interscience;

Chapin, F. S., Matson, P. A., \& Mooney, H. A. (2002). Principles of Terrestrial Ecosystem Ecology. Springer Verlag. Available at https://www.springer.com/gp/book/9780387216638.

Fertilizer Recommendation Guide (2012). Bangladesh Agricultural Research Council (BARC), Farmgate, Dhaka 1215, Bangladesh. p. 274.

Etigale, E. B., Ajayi, S., Udofia, S. I., \& Moses, M. U. (2013). Assessment of stand density and growth rate of three tree species in an arboretum within the University of Uyo, Nigeria. Journal of Research in Forestry, Wildlife and Environment. 6(1), 8-16.

Gomez, K. A., \& Gomez, A. A. (1984). Statistical Procedures for Agricultural Research. 2nd Edition, John Wiley and Sons, New York. p. 680.

Hasan, M. K., Mia, M. N., \& Islam, K. K. (2016). Geochemical analysis of forest floor leaf litters of Madhupur Sal forest of Bangladesh. Fundamental and Applied Agriculture, 1(1), 23-27.

Hossain, G. M., \& Bhuiyan, M. A. H. (2015). Spatial and temporal variations of organic matter contents and potential sediment nutrient index in the Sundarbans Mangrove forest, Bangladesh. Journal of Civil Engineering, 20(1), 163-174.

Hossain, M. A., Hossain, M. K., Alam, M. S., \& Uddin, M. M. (2015). Composition and Diversity of Tree Species in Kamalachari natural forest of Chittagong South Forest Division, Bangladesh. Journal of Forest and Environmental Science, 31(3), 192-201.

Hossain, M. A., Hossain, M. K., Salam, M. A., \& Rahman, S. (2013). Composition and Diversity of Tree Species in Dudhpukuria-Dhopachori Wildlife Sanctuary of Chittagong (South) Forest Division, Bangladesh. Research Journal of Pharmaceutical, Biological and Chemical Sciences, 4(2), 1447-1457.

Hossain, M. Z., Aziz, C. B., \& Saha, M. L. (2012). Relationships between soil physicochemical properties and total viable bacterial counts in Sundarbans mangrove forests, Bangladesh. Dhaka University Journal of Biological Sciences, 21(2), 169-175.

Jackson, M. L. (1958). Soil Chemical Analysis. Prentice-Hall, Inc., New Jersey. Pp. 205-226.

Joshi, H. G., \& Ghose, M. (2014). Community structure, species diversity, and aboveground biomass of the Sundarbans mangrove swamps. Tropical Ecology, 55(3), 283-303.

Mamun, A., Hossain, M. A., Hossain, M. K., \& Alam, S. (2015). Quantifying diversity and composition of tree species in secondary hill forests of Chunati for Bangladesh. The Indian Forester, 141(5), 566-572.

Maniruzzarnan, M., Zaman, M. W., \& Islam, M. K. (2009). Assessment of the nutrient status of the forest soils as compared to cultivated soils of the Sundarbans of Bangladesh. Journal of Sher-e-Bangla Agricultural University, 3(1), 88-96.

Muhibbullah, M., Nurul Amin, S. M., \& Chowdhury, A. T. (2005). Some physicochemical parameters of soil and water of Sundarbans Mangrove Forest, Bangladesh. Journal of Biological Sciences, 5(3), 354-357.

Ogner, G. (1980). Automatic determination of boron in water samples and soil extracts. Communications in Soil Science and Plant Analysis, 11(12), 1209-1219.

Page, A. L., Miller, R. H., \& Keeny, D. R. (1989). Methods of soil analysis. American Society of Agronomy. Madison, Wisconsin, USA. 2(2), 36. 
Peterson, L. (2002). Analytical Methods Soil, Water Plant Material Fertilizer. Soil Research division institute. Pp. 2124.

Ramamurthy, V., Radhika, K., Kavitha, Amirthanayagi, A., \& Raveendran, S. (2012). Physico-chemical analysis of soil and water of Vedaranyam mangrove forest, Tamil Nadu, India. International Journal of Advanced Life Sciences, 3(1), 65-71.

Rao, V. V. P., \& Rao, B. P. (2014). Physicochemical Analysis of Mangrove Soil in the Machilipatnam Coastal Region, Krishna District, Andhra Pradesh. International Journal of Engineering Research and Technology, 3(6), 10-12.

Rashid, S. H., Reinhard, B., Hossain, A. B. M. E., \& Khan, S. A. (2007). Undergrowth species diversity of Sundarbans mangrove forest (Bangladesh) in relation to salinity. Berlin Institute of Landscape and Plant Ecology-320, University of Hohenheim, Stuttgart, 2008, Germany, 17, 41-56.
Sadiqul Amin, M. (2016). Macro nutrient status of Sundarbans forest soils. Project Thesis. Soil Science Discipline, Khulna University, Khulna, Bangladesh. Pp. 1-60.

Walkley, A., \& Black, I. A. (1934). An Examination of a degtjareff method for determining soil organic matter and a proposed modification of the chromic acid titration method. Soil Science, 37, 29-38. 